\title{
Economic Aspects of Organizing High-technology Resource Saving Production in the Forest Sector of Russia
}

\author{
Submitted 08/01/19, 1st revision 18/03/19, 2nd rervision 14/04/19, accepted 03/06/19 \\ Morkovina S.S., ${ }^{1}$ Panyavina E.A. ${ }^{2}$, Platonov A.D. ${ }^{3}$, Kolesnichenko E.A. ${ }^{4}$
}

\begin{abstract}
:
Purpose: The article aims at assessing the possibility of organizing high-tech production in the Russian forest industry.

Structure/Methodology/Approach: To switch to high-tech and resource-saving technologies in the production of sleepers, it is necessary to assess the influence of a few factors: the cost of production of innovative products, the demand for innovative products, the lifetime of innovative products. To assess the demand, we have used an expert survey.

Results: The cost of producing railroad sleepers from modified wood has been established. The use of cheaper softwood wood as raw material (birch, aspen, alder, poplar, etc.) which makes it possible to reduce the cost of production of the sleepers is a competitive advantage of the innovative technology.

Practical implications: It has been established that in the future we should expect an increase in demand for the sleepers made of modified wood, especially in the European part of Russia.

Originality/Value. The main contribution of this study is the rationale for the transition to the concept of environmental savings in the Russian forest industry. The use of modified wood in the production of sleepers is economically viable and can be an alternative when diversifying production.
\end{abstract}

Keywords: High-tech manufacturing, forestry, investment attractiveness, modified wood.

JEL Code: C14, C81, E61, Q23, Q51.

Paper Type: Research article in Special Issue dedicated to Russian Economy.

Section 8: Business and Economic Issues.

Acknowledgement: The article is prepared in the framework of the state assignment number 11.3960.2017/4.6.

\footnotetext{
${ }^{1}$ Doctor of Science (Economics), Professor, Voronezh State University of Forestry and Technologies named after G.F. Morozov, Voronezh, Russia, tc-sveta@mail.ru

${ }^{2}$ Assistant Professor (Economics), Department of Management and Economics of Entrepreneurship, Voronezh State University of Forestry and Technologies named after G.F. Morozov Voronezh, Russia, panyavina-e-a@mail.ru

${ }^{3}$ Doctor of Science (Technicals), Professor, Voronezh State University of Forestry and

Technologies named after G.F. Morozov, Voronezh, Russia, aleksey66@ya.ru

${ }^{4}$ Doctor of Science (Economics), Professor, Head of Chair "Management of Human resource”, Tambov state university named after G.R. Derzhavin, Tambov, Russia, ekolesnichenko@live.ru
} 


\section{Introduction}

Development of innovations in the industrial sector of Russia is becoming a state priority since the beginning of the XXI century, and industrial policy is beginning to be viewed inextricably linked to innovation. Structural problems of national industry are directly related to the insufficient level of its innovation development (Panyavina, 2017). Innovations are declared to be the main instrument for national industry modernization and its competitiveness enhancement. Russian railway transport is one of the largest railway networks in the world. In 2016, the operational length of general-purpose railways in the Russian Federation is 85.3 thousand $\mathrm{km}$. The total length of railway tracks is 121 thousand $\mathrm{km}$. Russia ranks third after the United States and China in terms of the railway length. In terms of cargo turnover, the Russian Federation is the leader in Europe and takes the second place in the world.

Sleepers are elements of the upper structure of railway track and they are intended to ensure the constancy of the gage, transfer the load from the rails to the ballast pad, and fix the track on the roadway. Choosing a material for the manufacture of sleepers is based on such major factors as cost per lifetime and performance specifications (Kuryanova, 2018). The railways of the world mainly use several types of sleepers: wooden; reinforced concrete; steel and polymeric (plastic) ones. Service life of pine sleepers is no more than 12-15 years, reinforced concrete sleepers - about 30-50 years (Mikheevskaya, 2018). The main disadvantages of reinforced concrete sleepers include: lack of damping properties, leading to the destruction of mounted wheels; increased incidence of electric shock due to high current conduction by reinforced concrete; forced replacement of depreciated damping pads every 7-8 years, resulting in high costs in the operation of the railway.

Since the 1990s, Japan and the United States have begun to explore, limitedly produce and use plastic sleepers, but their cost is much higher than the cost of other sleepers. In Western Europe, Japan and other countries, where wood products are scarce and expensive, sleepers are usually made of imported hardwood. Wooden sleepers with special impregnation are still widely used in the USA. In Russia, the cost of impregnated pine sleepers ranges from 15.3 to 19.2 USD per sleeper, and the upward price trend continues. This is due to the fact that reserves of assortments of coniferous species with a diameter of at least $26 \mathrm{~cm}$ and more, used in the production of sleepers, are almost depleted in the Central Zone and in the Urals, and there are very few branch logging roads in Siberia and in the North, where the reserves are significant (Morkovina, 2018).

The main barriers when choosing wooden sleepers are short service life, quality of impregnation and depleted raw materials base (Shamaev and Efimova 2018). At the same time, a large amount of soft hardwoods (birch, aspen, alder, poplar, etc.) annually decay in Russian logging sites. 
Sleepers with high-quality impregnation which are made of modified hardwood are not inferior in their physical and mechanical properties to sleepers made of coniferous species. The predicted service life of sleepers made of modified wood may be significantly higher than that of wooden sleepers made of coniferous species (Shamaev, Medvedev 2018).

Since the planned sleepers made of modified wood, according to the requirements to railway tracks development, should be identical to the sleepers made of natural wood according to its purpose, shape, sizes, processing method of defect tolerances, but with improved performance characteristics, it is therefore necessary to establish how competitive the innovative production of sleepers from modified wood is.

\section{Materials and Methods}

The production costs of modified wood sleepers have been found to assess the possibility of transition to new technologies. The production technology of modified wood sleepers differs from traditional solutions by combining three operations in time: impregnation, drying, and wood pressing (Shamaev, 2015). The costs that form production costs are grouped in accordance with their economic content by the following elements:

- Material costs (minus cost of returnable waste);

- Labor costs;

- Insurance premiums;

- Depreciation of fixed assets;

- Other costs.

Criteria based on discounted (time) estimates have been used to determine the effectiveness of innovative production:

- Net present value (NPV);

- The rate of return on invested capital (profitability index of investments);

- Internal rate of return (IRR);

- Discounted payback period.

An expert method has been used to determine the investment attractiveness of resource-saving production development of modified wood sleepers. Informational letters with the application of questionnaires and a proposal to take part in the study has been prepared and sent (including sending by e-mail) for the study. Methods of comparison, correlation, questioning, and observation have been used in the study:

$\checkmark$ Surveys of employees working at enterprises producing wooden sleepers;

$\checkmark$ Identifying and establishing the importance of factors affecting the development of resource-saving sleepers' production from modified wood, the coordination of expert opinions has been carried out based on calculating the dispersion of Kendall's concordance coefficient;

$\checkmark$ Desk research, including assessment of economic efficiency of organizing resource-saving production of modified wood sleepers. During desk 
research the experience and forms of innovation support in the forest sector of Russia have been studied.

\section{Results and Discussion}

During the expert survey, it was established that a significant part of the heads of enterprises is interested in the application of innovative technologies as the basis for reducing production costs. At the same time, experts have noted the presence of significant risks of transition to new production and high level of interest rates when attracting investments, which is also confirmed in the works of researchers of this issue (Morkovina, 2017). These two factors, according to experts, significantly affect the introduction of new technologies in the forest sector of Russia (Figure 1).

According to the survey results of employees working at enterprises producing wooden sleepers, it has been found that the production of wooden sleepers in Russia is currently in a state of depression. When asked about the innovative development of an enterprise, $68 \%$ of surveyed respondents have noted a growing need for innovation. Enterprises using technological innovations in their activities take 22\% of the respondents. $17 \%$ of surveyed respondents have described the production of wooden sleepers as a loss-making activity, while significant profit is indicated only by $9 \%$ respondents. A significant part of experts believes that the high level of expenditures for conducting exploratory research and long preparation period for the transition to the release of new products also hold back the development of innovative technologies (56.3 and $42.4 \%$ of the experts answered positively).

Figure 1. Priorities for the development of innovative technologies in the forest sector of Russia

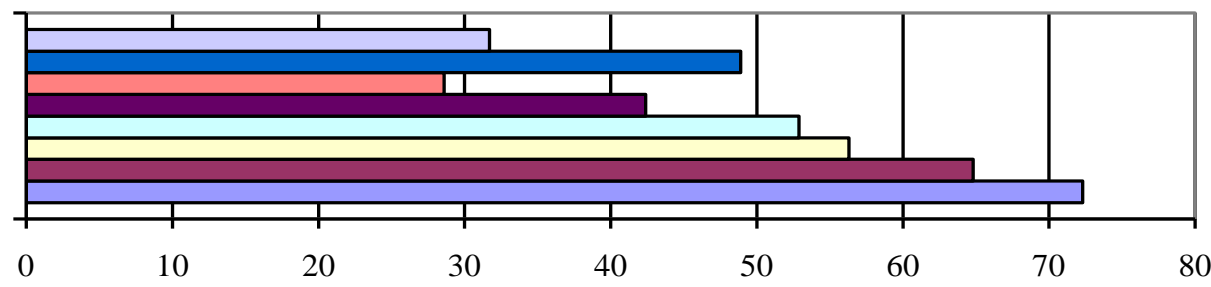

Industrial engineering risks

High interest rates

High R \& D costs

Availability of substitute products

Long preparation period

The need for qualified staff

Lack of tax and financial benefits $\square$ High industry competition 
Absence of tax benefits and preferences for enterprises engaged in research and development activities and creating innovative products also negatively affects the development of high-tech and resource-saving industries in the Russian forest sector (Morkovina, 2017). 69\% of respondents said that measures of state support for innovation were insufficient. At the same time, only $7 \%$ of the surveyed experts from the analyzed enterprises took advantage of state support measures on a regular basis. Experts have pointed out financial and investment risks among the main ones when organizing production. Calculations have been carried out and the production cost of railway sleepers from modified wood is found using the cost approach (Table $1)$.

Table 1. Production cost of railroad sleepers made of modified wood

\begin{tabular}{|l|l|l|}
\hline \multirow{2}{*}{ Cost items } & \multicolumn{2}{|l|}{$\begin{array}{l}\text { The sum of costs to produce sleepers from } \\
\text { modified wood }\end{array}$} \\
\cline { 2 - 3 } & Per 1 sleeper, USD & $\begin{array}{l}\text { For the whole } \\
\text { batch, USD }\end{array}$ \\
\hline 1. Cost of raw materials & 7.80 & 16412.6 \\
\hline 2. Salary of basic and additional workers & 7.70 & 16353.8 \\
\hline 3. Insurance premiums & 2.40 & 5123.0 \\
\hline $\begin{array}{l}\text { 4. Cost of maintenance and operation of } \\
\text { equipment }\end{array}$ & 7.80 & 16646.1 \\
\hline 5. Shop costs & 1.06 & 2246.1 \\
\hline 6. General running costs & 0.07 & 153.8 \\
\hline 7. Manufacturing cost & 26.9 & 56969.0 \\
\hline 8. Selling costs & 0.53 & 1138.4 \\
\hline 9. Full costs & 27.43 & 58107.4 \\
\hline
\end{tabular}

The production cost of a batch of sleepers made of modified wood is $\$ 56969.0$ thousand, the full cost is $\$ 58,107.4$ thousand, and the full cost of one sleeper is $\$$ 27.43. The largest share in the structure of production cost of railway sleepers is occupied by the costs of maintenance and operation of equipment $-29.2 \%$, the cost of raw materials and materials - $28.8 \%$. Multivariate calculations have made it possible to justify the production of railway sleepers from modified wood for a period of 10 years and to conduct a comparative analysis of the possibilities of transition to innovative technologies for the production of modified wood sleepers. The results of discounted payback period calculations and the economic efficiency of the production of modified wood sleepers are presented in Table 2.

Table 2. Economic efficiency of modified sleeper production development, at a comparison rate of $12 \%$

\begin{tabular}{|l|l|l|l|l|l|l|l|l|l|l|}
\hline Indicators & $\begin{array}{l}1^{\text {st }} \\
\text { year }\end{array}$ & $\begin{array}{l}2^{\text {nd }} \\
\text { year }\end{array}$ & $\begin{array}{l}3^{\text {th }} \\
\text { year }\end{array}$ & $\begin{array}{l}4^{\text {th }} \\
\text { year }\end{array}$ & $\begin{array}{l}\text { th } \\
\text { year }\end{array}$ & $\begin{array}{l}6^{\text {th }} \\
\text { year }\end{array}$ & $\begin{array}{l}7^{\text {th }} \\
\text { year }\end{array}$ & $\begin{array}{l}8^{\text {th }} \\
\text { year }\end{array}$ & $\begin{array}{l}9^{\text {th }} \\
\text { year }\end{array}$ & $\begin{array}{l}10^{\text {th }} \\
\text { year }\end{array}$ \\
\hline $\begin{array}{l}\text { Income, } \\
\text { thousand } \\
\text { rubles }\end{array}$ & 75.5 & 78.5 & 81.7 & 84.98 & 88.36 & 91.90 & 95.58 & 99.41 & 103.38 & 107.52 \\
\hline Costs, & - & -50.3 & -52.7 & -55.1 & -57.7 & -60.4 & -63.3 & -66.35 & -69.53 & -72.93 \\
\hline
\end{tabular}




\begin{tabular}{|c|c|c|c|c|c|c|c|c|c|c|}
\hline $\begin{array}{l}\text { thousand } \\
\text { rubles }\end{array}$ & 152.6 & & & & & & & & & \\
\hline $\begin{array}{l}\text { Net cash } \\
\text { flow } \\
\text { (NCF), } \\
\text { thousand } \\
\text { USD }\end{array}$ & -77.0 & 28.2 & 29.0 & 29.8 & 30.63 & 31.43 & 32.24 & 33.0 & 33.84 & 34.6 \\
\hline $\begin{array}{l}\mathrm{NCF}, \\
\text { cumulative, } \\
\text { thousand } \\
\text { USD }\end{array}$ & -77.0 & -48.9 & -19.9 & 9.90 & 40.52 & 71.96 & 104.2 & 137.26 & 171.10 & 205.70 \\
\hline $\begin{array}{l}\text { Discount } \\
\text { coefficient }\end{array}$ & 1.000 & 0.941 & 0.886 & 0.834 & 0.785 & 0.738 & 0.695 & 0.654 & 0.616 & 0.579 \\
\hline $\begin{array}{l}\text { Discount } \\
\text { NCF, } \\
\text { thousand } \\
\text { USD }\end{array}$ & -77.0 & 25.8 & 24.3 & 22.8 & 21.5 & 20.2 & 19 & 17.8 & 16.7 & 15.6 \\
\hline $\begin{array}{l}\mathrm{NCF} \text {, } \\
\text { cumulative, } \\
\text { thousand } \\
\text { rubles }\end{array}$ & -77.0 & -51.2 & -26.9 & -4.0 & 17.4 & 37.6 & 56.6 & 74.4 & 91.2 & 106.8 \\
\hline $\begin{array}{l}\text { Simple } \\
\text { payback } \\
\text { period, } \\
\text { years }\end{array}$ & 3.7 & & & & & & & & & \\
\hline $\begin{array}{l}\text { Discounted } \\
\text { payback } \\
\text { period, } \\
\text { years }\end{array}$ & 4.2 & & & & & & & & & \\
\hline $\begin{array}{l}\text { NPV (net } \\
\text { present } \\
\text { value), } \\
\text { thousand } \\
\text { USD } \\
\end{array}$ & 111.1 & & & & & & & & & \\
\hline $\begin{array}{l}\text { IRR } \\
\text { (internal } \\
\text { rate of } \\
\text { return), \% }\end{array}$ & 40 & & & & & & & & & \\
\hline $\begin{array}{l}\text { Rate of } \\
\text { return on } \\
\text { invested } \\
\text { capital, \% }\end{array}$ & 106 & & & & & & & & & \\
\hline
\end{tabular}

Value of NPV > 0, therefore, the production of modified wood sleepers is efficient. Discounted payback period for an investment project to produce sleepers made of modified wood is 4.2 years. The competitive advantages of the new technology have been found during comparative assessment of organization of sleeper production from modified wood and traditional sleeper production. The use of cheaper softwood as a raw material (birch, aspen, alder, poplar, etc.) reduces the cost of sleeper production, despite the use of antiseptics and stabilizers. The dynamics of expected demand and prices for sleepers produced by traditional and innovative methods are presented in Figure 2. 
Figure 2. The dynamics of expected demand and prices for sleepers produced by traditional and innovative methods in Russia
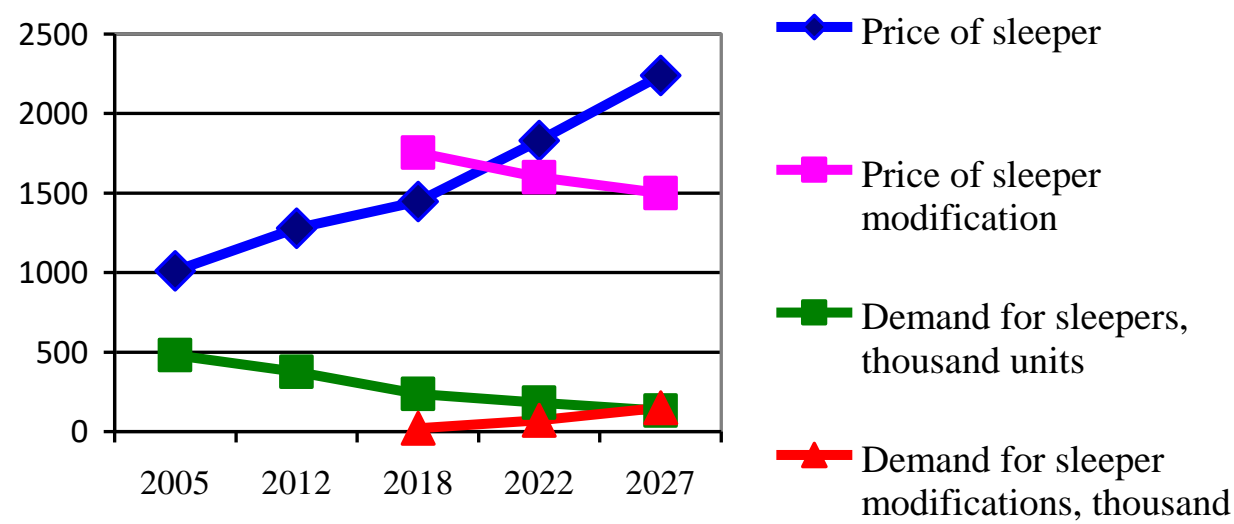

Obviously, the demand for modified sleepers will grow in future, determining the displacement of traditional technology. Coniferous wood purchased from logging enterprises of the Northern Urals and Siberia is used in the production of wooden sleepers. The main criterion is the quality of these sleepers - strength, durability, biostability and dimensional stability, as well as their cost.

Raw materials to produce sleepers are conifers, mainly pine. But with a shortage of these species, sleepers can be made of soft hardwoods. The cost of raw materials from these species is lower than from coniferous ones. The density of soft hardwoods is lower than that of coniferous ones; hence the strength is also lower.

Raw materials to produce sleepers must be deeply impregnated with antiseptic and stabilizer composition, i.e. chemical and mechanical wood modification must be carried out to increase the lifetime of wooden sleepers, their biological and dimensional stability. Useful lifetime of railway sleepers depends on the impregnating composition and technology of impregnation. Therefore, the promise of organizing the production of sleepers from modified wood is obvious. It is necessary to create new high-tech resource-saving production of railroad sleepers made of modified wood with improved performance indicators (strength, hardness, dimensional stability and wear resistance) exaggerating existing production in the forest sector of Russia.

\section{Conclusions}

Despite the growing interest of the state in the development of forest industry and the sphere of innovations, it is not still possible to overcome structural imbalances in this industry. Problem areas in the forest sector of Russia remain the same as several decades ago: relatively weak level of innovative activity of industrial enterprises; low level of industry interaction with science; poor development of venture capital and insufficient measures to support innovation. The use of cheaper soft hardwoods 
(birch, aspen, alder, poplar, etc.) as a raw material enables to reduce the cost of sleeper production. It is a competitive advantage of innovative technology. The production cost of sleepers made of modified wood is $27.43 \mathrm{USD}$, and it ensures the competitiveness of new products at a price in comparison with traditional analogues. In future, we should expect growth in demand for modified wood sleepers, especially in the European part of Russia.

\section{References:}

Epifanova, T., Kolesnikov, Y., Usenko, A., Parshina, E. 2016. Peculiarities of State Regulation of Innovational Activity of Enterprise in the Global Economy. Contemporary Economics, 10(4), 343-352, DOI: 10.5709/ce.1897-9254.221.

Epifanova, T.V., Verveda, V.V. 2017. «Green» settlement as a basis for sustainable development of the regions. Probely v rossiyskom zakonodatl'stve, 3, 169-170, www.urvak.ru/journals/probely-v-rossiyskom/.

Kuryanova, T.K., Platonov, A.D., Mikheevskaya, M.A., Snegireva, S.N., Pervakova, E.A. 2018. Theoretical bases of obtaining modified wood. Forestry Engineering Journal (in Russian-Lesotehnicheski), 8, 1(29), 146-154.

Mikheevskaya, M.A., Platonov, A.D., Snegireva, S.N., Kuryanova, T.K., Kiseleva, A.V., Pervakova, E.A. 2018. Theoretical foundations of technology for obtaining modified wood. Engineering Bulletin of the Don, 2, 65.

Morkovina, S.S., Rafailov, M.K. 2018.Scenario approach in strategic planning of development of the forest complex of Russia. Bulletin of Rostov State University of Economics (RSUE), 3(63), 111-123.

Morkovina, S., Bezrukova, T., Sibiryatkina, I., Bukhtoyarov, N., Leontyev, E. 2017. Risk factors for the development of entrepreneurship in forest sector of Russia. In the collection of papers: Proceedings of the 29th International Business Information Management Association Conference - Education Excellence and Innovation Management through Vision 2020: From Regional Development Sustainability to Global Economic Growth, 1975-1981.

Morkovina, S.S., Sokolinskaya, Y.M., Bukhtoyarov, N.M., Safonova, N.A. 2017. Deformation factors of the entrepreneurship development in the industry segments of the economy of the Russian Federation. European Research Studies Journal, 20(3B), 403-411.

Panyavina, E.A., Chirkova, M.B., Cheglakova, S.G., Pankov, V.V. 2017. The role and place of the crisis traps in the development of the small business of the forest sector in the Russian economy. European Research Studies Journal, 20(3B), 480-489.

Shamaev, V.A., Efimova, T.V., Ishchenko, T.L. 2018. Production of High Strength Plywood From Birch Wood, 60(2), 135-141.

Shamaev, V.A., Medvedev, I.N., Parinov, D.A., Shakirova, O.I., Anisimov, M.V. 2018. Investigation of modified wood as a material power transmission pole produced by self-pressing method. Acta Facultatis Xylologiae, 60(2), 25-32.

Shamaev, V.A. 2015. Obtaining modified wood by chemical and mechanical method and investigation of its properties. Forestry Engineering Journal (in Russian Lesotehnicheski), 5, 4(20), 177-187. 